\title{
WWOOFING KAO NOVI OBLIK TRANSFORMATIVNOG TURIZMA U HRVATSKOJ
}

\author{
Larisa Dukić, Irena Ateljević i Renata Tomljenović
}

\author{
Institut za turizam \\ Vrhovec 5, 10000 Zagreb \\ e-mail: larisa.dukic@iztzg.hr
}

\section{Sažetak}

Danas je diljem svijeta zamjetan društveni fenomen u kojem putovanja služe kao katalizator kroz koji odgovorni gradani nastoje promijeniti sebe i svijet u kojem žive. U ovom radu bit će predstavljen trend WWOOFinga kao specificnog oblika volonterskog ekoturizma te kao potencijalnog primjera transformativnog oblika turizma u Hrvatskoj. Upotrijebljen metodološki pristup sastojao se od analize literature i podataka dostupnih na web stranici nezavisnih organizacija WWOOFa te dubinskog intervjuiranja domaćina WWOOFa u Hrvatskoj. Istraživanje je pokazalo kako primarnu motivaciju domaćina za uključivanje u WWOOF čini osiguravanje dodatne pomoći na farmi, upoznavanje ljudi i kultura iz različitih dijelova svijeta te širenje znanja o održivom načinu života i organskoj poljoprivredi. Primarnu motivaciju volontera za sudjelovanje u WWOOFingu čini želja za učenjem i aktivnim sudjelovanjem u organskoj proizvodnji i alternativnom načinu života, bijeg od svakodnevnice te potraga za novim i autentičnim iskustvima, mogućnost jeftinijeg načina putovanja i boravka $u$ destinaciji. WWOOFing se u značajnoj mjeri razlikuje od konvencionalnog turizma te pokazuje izrazit transformativni potencijal temeljen na iskustvu radne $i$ kulturne razmjene, izravnom uključivanju u svakodnevnicu domaćina te učenju o organskoj poljoprivredi $i$ održivosti alternativnog načina života.

Ključne riječi: WWOOF, ekoturizam, volonterski turizam, održivost, transformacija

\section{UVOD}

Brojni znanstvenici i stručnjaci iz prirodnih i društvenih znanosti, ekonomisti, politički aktivisti i društveni poduzetnici opisuju zamjetnu pojavu promjene globalne paradigme u 21. stoljeću. Iako koriste različite termine i pristupe prilikom opisivanja ove pojave socio-kulturne, ekonomske i filozofske promjene svijesti, vrijednosti i pogleda na svijet, svi autori ukazuju na isti smjer - pojavu planetarne vizije prema kojoj ljudi počinju shvaćati da smo svi povezani u jedan sustav koji nas čini međuovisnim, ranjivim i odgovornim prema Zemlji (Ateljević i Tomljenović, 2016). Promjena paradigme rezultat je svijesti o alarmantnom stanju svjetskog sustava i njegovih neodrživih praksi o kojima svakodnevno svjedočimo kroz vijesti o brojnim gospodarskim i financijskim krizama, ratovima, gladi i prirodnim katastrofama, a njome se nastoji nadići postojeću neodrživu 
materijalističku paradigmu i stvoriti pravedniji svijet oblikovan višim vrijednostima te smislenijim i odgovornijim životima. Upravo u tom kontekstu javlja se promišljanje o turizmu kao društvenoj snazi koja utječe na pojedince, društva i prostore te traženje odgovora na pitanje može li turizam (i kako) pridonijeti oblikovanju nove društvene vizije blagostanja pojedinaca, pravednih društava i zdravih okoliša. Zaista, danas je na strani turističke potražnje zamjetna pojava društveno odgovornih potrošača koji sve veću vrijednost pridaju duhovnosti, zdravom načinu života, ekološkoj i društvenoj pravdi te ekološkoj održivosti (Ateljević, 2009; 2011; Dwyer i sur., 2017; Pritchard i sur., 2011). Društveno odgovorni potrošači odluku o potrošnji donose na temelju ukupne vrijednosti, a ne najniže cijene; traže značajna iskustva, a ne objekte; aktivno zajednički stvaraju sadržaj, proizvode i iskustva te su spremni platiti više za proizvode i usluge proizvođača koji dijele slične vrijednosti. Takvi osviješteni potrošači u ulozi turista razlikuju se od konvencionalnih turista svojim vrijednostima, stavovima i motivima. Koriste putovanja kako bi volontirali i sami pridonijeli pozitivnim prirodnim i / ili društvenim promjenama; cijene ono što je sporo, malo i jednostavno; međusobno su povezani i komunikativni te tragaju za značajnim iskustvima. Osim na strani turističke potražnje, zamjetna je i pojava društveno odgovornih turističkih poduzetnika koji svoju ponudu oblikuju na temelju vlastitih vrijednosti i stavova koji su uvelike oblikovani težnjom ostvarivanja vizije održivog svijeta mira i sloge. Takve trendove „novog turizma“ nazivamo transformativnim, a među njima se svojim vrijednostima i obilježjima posebno ističe WWOOFing. WWOOF je „svjetski pokret koji povezuje volontere (WWOOFere) s organskim poljoprivrednicima i uzgajivačima (domaćinima $W W O O F a$ ) kako bi promovirao kulturna i edukativna iskustva temeljena na povjerenju i nenovčanoj razmjeni te tako dao vlastiti doprinos izgradnji održive globalne zajednice" (WWOOF, 2017). Funkcionira na principu (nenovčane) razmjene između volontera i domaćina, omogućujući volonterima smještaj, hranu i mogućnost učenja o organskoj poljoprivredi u zamjenu za sudjelovanje u svakodnevnim, pretežno poljoprivrednim poslovima na organskoj farmi domaćina. WWOOFing možemo promatrati kao specifični oblik volonterskog ekoturizma proizašao iz pokreta $W W O O F$ koji pojedincima omogućuje da „putuju, volontiraju i dijele održiv način života“" (McIntosh i Bonnemann, 2006). U posljednjih 15-ak godina zamjetan je ubrzani porast potražnje za WWOOFingom što je posljedica rastuće ekološke osviještenosti, interesa za organsku proizvodnju i održiv način života; ekspanzije backpackinga i alternativnih oblika turizma, posebice ekoturizma i volonterskog turizma; rastućeg interesa za alternativnim, nenovčanim iskustvima temeljenim na razmjeni (npr. CouchSurfing) i rastuće „ekonomije iskustva“ (Deville i sur., 2015b; Wearing, 2015). Nalazi se na dodiru dvaju rastućih sektora - održivog turizma i održive poljoprivrede (Deville i Wearing, 2013) u čijem kontekstu termini „organsko“ i „održivost“ odražavaju ideje o očuvanju resursa i moralno ispravnom načinu postupanja prema drugima $i$ okolišu, specifične ideje o pravednim ekonomskim praksama, društvenoj pravdi, zajed-

1 Engl. World Wide Opportunities on Organic Farms 
ničkom stanovanju i jednakosti (Kosnik, 2013). Danas je u pokret WWOOF uključeno više od sto država svijeta među kojima je i Hrvatska.

Budući da WWOOFing predstavlja relativno novu pojavu u Hrvatskoj te dosad nije istražen u njenom kontekstu, provedeno istraživanje imalo je dva ključna cilja: (i) steći (početni) uvid u obilježja WWOOFinga u Hrvatskoj općenito te (ii) istražiti WWOOFing u kontekstu transformativnog turizma.

\section{METODOLOGIJA}

Upotrijebljen metodološki pristup sastojao se od prikupljanja i analize relevantne stručne i znanstvene literature, analize podataka o domaćinima WWOOFa u Hrvatskoj dostupnim na web stranici nezavisnih organizacija WWOOFa (WWOOF Croatia, 2017) te dubinskog intervjuiranja domaćina WWOOFa u Hrvatskoj (Tomljenović i sur., 2015). $\mathrm{Na}$ temelju pregleda dosadašnje literature i izvora o WWOOFu stečen je uvid u pojavu, razvoj i ciljeve pokreta WWOOF te WWOOFing kao oblik turizma, njegova obilježja i transformativni potencijal. Analizom podataka dostupnih na stranici nezavisnih organizacija WWOOFa stečen je uvid u pojavu, razvoj i obilježja WWOOFinga u Hrvatskoj, dok je metodom dubinskog intervjuiranja domaćina WWOOFa u Hrvatskoj istraženo nekoliko relevantnih istraživačkih pitanja bitnih za dublje razumijevanje WWOOFinga u kontekstu hrvatskog (transformativnog) turizma: (i) motivacija domaćina WWOOFa za ulazak u organizaciju WWOOFa; (ii) profil WWOOFera i dosadašnja iskustva domaćina WWOOFa s WWOOFerima, (iii) usporedba WWOOFinga s konvencionalnim i transformativnim turizmom. Dubinsko intervjuiranje provedeno je u razdoblju između 25. ožujka i 07. travnja 2015. godine. U vrijeme provođenja istraživanja u organizaciju WWOOFa bilo je uključeno 13 domaćina WWOOFa, od čega su na temelju prigodnog uzorka četiri uključena u istraživanje. Kazivači su odabrani na temelju dostupnih kontakt podataka na stranici nezavisnih organizacija WWOOFa, bez prethodnog učlanjenja autora u organizaciju WWOOF. Budući da je primarni cilj ovog istraživanja bilo stjecanje početnog uvida u obilježja WWOOFinga u Hrvatskoj i njegov transformativni potencijal, prigodni uzorak uzet je kao prihvatljiv. Tri dubinska intervjua provedena su telefonskim putem, dok je jedan proveden osobno. Prosječno trajanje intervjua iznosilo je 45 minuta. Dubinski intervjui sastojali su se od 19 pitanja otvorenog tipa oblikovanih oko ključnih istraživačkih tema.

\section{TRANSFORMATIVNI TURIZAM}

Pojedini autori promjenu načina razmišljanja, vrijednosti i (stila) života vezanu uz turističko iskustvo i njegove potencijalne ishode nazivaju transmoderni turizam (Ateljević, 2009; 2011), transformativni turizam (Reisinger, 2013a; 2015), transformativna putovanja (Kottler, 1997; Ross, 2010; Lean, 2009) ili osviještena putovanja (Pollock, 2015). Termin „transformativno putovanje“ prvi je uveo Kottler (1997) u svojoj praksi psihoterapije, u sklopu koje je pomogao klijentima da se uključe u terapeutska transfor- 
mativna putovanja, smatrajući da niti jedna druga ljudska aktivnost nema veći potencijal mijenjati percepciju ili način na koji oblikujemo vlastiti život. Na njegov diskurs kasnije se u svom terapeutskom radu oslanja Ross (2010) koja smatra da transformativna putovanja predstavljaju sredstvo radikalne transformacije individualne i kolektivne svijesti u kratkom vremenskom razdoblju i na ugodan način. Lean (2009) istražuje potencijal iskustva putovanja kao pokretača promjena dugoročnog načina razmišljanja i ponašanja u kontekstu održivog turizma te smatra kako bi njegov primarni cilj trebalo biti poticanje, inspiriranje i njegovanje pojedinaca kao „ambasadora održivosti“ koji će donijeti društvene promjene i izroditi ideale poput održivog razvoja. Ateljević (2009; 2011) u svom znanstvenom diskursu odlazi korak dalje i transmoderni turizam vidi kao sredstvo s kojim se mogu nadići postojeće epistemološke i političke dihotomije, odnosno nadići postojeće kulturne politike u kojoj je jedna kultura dominantna i superiornija nad drugima, mijenjajući odnos prema rasi, spolu, tradiciji, kulturi, ekonomiji i drugome. Nadalje, smatra da pojava novih oblika turizma i turističkih iskustava koja potencijalno sadrže snagu za pomoć svijetu u ostvarivanju više razine osviještenosti istovremeno potvrđuje aktualnost globalne promjene paradigme. Reisinger je uredila dvije knjige o transformativnom turizmu iz perspektive turista (2013a) i domaćina (2015) u kojima donosi radove brojnih autora koji istražuju načine na koje putovanja i turizam mogu utjecati na promjenu ljudskog ponašanja i pozitivno utjecati na svijet. Sukladno tome, identificirala je pojedina turistička iskustva koja imaju takav potencijal, poput edukativnog, volonterskog, socijalnog, pravednog, religijskog i spiritualnog turizma, ekoturizma, backpackinga i WWOOFa (Reisinger 2013a; 2013b). U svom poglavlju o povezanosti putovanja, turizma i transformacije ističe kako alternativni oblici turizma imaju dublju svrhu i uključuju interakciju koja je participativna, humana i održiva te je vođena motivacijom za istraživanjem, samospoznajom, rastom i razvojem (Reisinger, 2013b). Pollock (2015) je razvila koncept osviještenih putovanja kao odgovor na neodrživ dominantni ekonomski model i brojne negativne posljedice masovnog turizma, poput prekomjernog pritiska na oskudne resurse vode, zemlje i energije ili pretvaranja jedinstvenih mjesta u robne proizvode. Osviješteni turizam vidi kao holistički, integralni pristup turističkom razvoju koji: (i) donosi vrijednost većem broju ljudi; (ii) podržava sav život i djeluje u harmoniji s prirodom; (iii) aktivno slavi i njeguje jedinstvenost mjesta i ljudi; (iiii) sudionicima omogućuje pozitivno iskustvo neto koristi i razvoj njihova punog potencijala kao živih bića; (iiiii) stvara smislen i održiv način života ljudima i poduzećima o kojima ovisi. Iako koriste različite termine, radovi spomenutih autora ukazuju na isti smjer - istraživanje potencijala turističkog iskustva u svrhu poticanja dugoročnih promjena načina razmišljanja, $s$ posebnim interesom za ulogu turizma kao pokretača pozitivnih promjena u društvu i prostoru te ostvarivanju ideala poput održivog načina života i razvoja. Da bi turizam bio transformativan, mora orijentirati turista prema problemima s kojima se društvo suočava, ljudima koji se $s$ njima suočavaju i rješenjima koja predlažu (Deville i Wearing, 2013). Na taj način dolazi do preispitivanja vlastitih stavova, vrijednosti i ponašanja do točke u kojoj postaju neodrživi, odnosno točke u kojoj dolazi do promjene paradigme iz egocentrične u ekocentričnu. 


\section{WWOOF- POJAVA, RAZVOJ, CILJEVI}

Pokret WWOOF pojavio se 1971. godine u Ujedinjenom Kraljevstvu. Osnovala ga je Sue Coppard potaknuta rastućom potrebom za (privremenim) boravkom na selu kao odgovorom na ubrzani ritam gradskog života te pokretom organske poljoprivrede koji se u to vrijeme pojavio u suvremenom, pretežno zapadnom društvu (WWOOF, 2017).

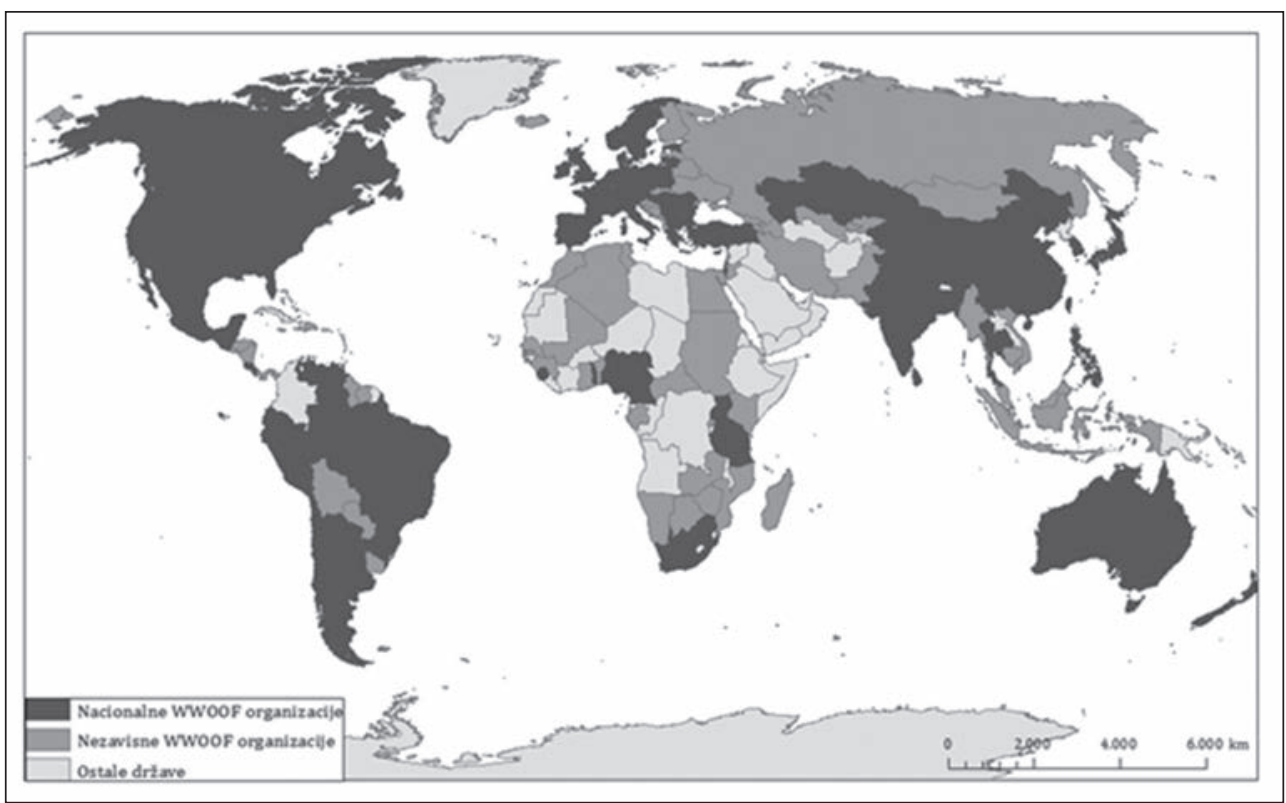

Izvor: WWOOF, 2017; WWOOF Independents, 2017

Slika 1. Geografska rasprostranjenost nezavisnih i nacionalnih organizacija WWOOFa

Isprva je $W W O O F$ bio zamišljen kao boravak tijekom vikenda na organskim farmama (čemu je svjedočilo i izvorno značenje akronima WWOOF - Working Weekends on Organic Farms), no $s$ vremenom je prerastao u pokret koji se proširio diljem svijeta i uvelike nadišao okvire vikend boravka. WWOOF je organiziran preko mreže nacionalnih i nezavisnih organizacija WWOOFa. Nacionalne organizacije WWOOFa (npr. WWOOF Australija ili WWOOF UK) čine države koje su osnovale vlastitu organizaciju WWOOFa. Nezavisne organizacije WWOOFa čine države koje nemaju vlastitu nacionalnu organizaciju WWOOFa, stoga se nalaze pod upravom Međunarodnog udruženja WWOOFa. Danas je u WWOOF uključeno 59 nacionalnih i 67 zavisnih organizacija WWOOFa (sl.1). 
Budući da ne postoji mogućnost svjetskog članstva u WWOOFu, zainteresirani volonteri i domaćini učlanjuju se u pojedinu organizaciju WWOOFa uplatom skromne godišnje članarine. Sve informacije o pojedinom domaćinu dostupne su putem mrežnih stranica, a obično uključuju: lokaciju farme, opis farme i poslova, tip smještaja, period otvoren za volontiranje, godinu učlanjenja u $W W O O F$, kontakt, popis jezika kojima govore domaćini te način prehrane (WWOOF, 2017). Postupak razmjene počinje kontaktiranjem domaćina zainteresiranog volontera, nakon čega se dogovaraju svi detalji razmjene. Volonter sam pokriva troškove putovanja, osiguranja i vize. Vrsta posla i slobodno vrijeme, kao i broj radnih sati, variraju ovisno o očekivanjima domaćina, odnosno vrsti pomoći koja im je potrebna, sposobnostima i volji volontera, sezoni i vremenskim prilikama (Alvarez, 2012; McIntosh i Bonnemann, 2006).

Temeljni ciljevi WWOOFa su (Kosnik, 2013):

- volonterima pružiti iskustvo organske proizvodnje iz prve ruke;

- domaćinima osigurati pomoć u održavanju organske proizvodnje kao bitnog dijela njihova alternativnog načina života;

- povezati gradsko stanovništvo sa seoskim,

- poticati razmjenu ideja, produbljivanje postojećih i stvaranje novih odnosa unutar organskog pokreta.

\section{WWOOFING KAO OBLIK TURIZMA, NJEGOVA OBILJEŽJA I TRANSFORMATIVNI POTENCIJAL}

Turistički stručnjaci koji su dosad istraživali WWOOFing usredotočuju se na WWOOFere prvenstveno kao međunarodne putnike (iako mogu biti i domaći), njihova kretanja od urbanih prema ruralnim prostorima i turističkih obilježja WWOOFinga (Kosnik, 2013). Brojni autori WWOOFing smatraju oblikom volonterskog turizma (Alvarez, 2012; Deville, 2015; Miller i Mair, 2015; Terry, 2014; Yamamoto i Engelsted, 2014), održivog turizma (Choo i Jamal, 2009; Deville i sur., 2015a; 2015b), seoskog ili agroturizma (Choo i Jamal, 2009; McIntosh i Bonnemann, 2006; Mcintosh i Campbell, 2001) te ekoturizma (Choo i Jamal, 2009; Nimmo, 2001; Yamamoto i Engelsted, 2014), pritom ga nerijetko svrstavajući u dodir $s$ barem dvama specifičnim oblicima turizma (npr. volonterskim turizmom i ekoturizmom).

McIntosh i Bonnemann (2006) istražuju WWOOFing kao oblik seoskog turizma na Novom Zelandu koji predstavlja „alternativno iskustvo boravka na organskim farmama“. Primarnu poveznicu sa seoskim turizmom čini njegovo odvijanje u ruralnom prostoru, iskustvo autentičnosti seoskog načina života i povezivanja s lokalnom zajednicom. Od boravka na komercijalnim turističkim farmama razlikuje se zbog osobnog ugovaranja razmjene (bez posrednika poput turističke agencije) koja je pritom nenovčana, volonterskom prirodom iskustva, aktivnim sudjelovanjem u životu domaćina i aktivnostima na farmi koje se dijele između volontera i domaćina, mogućnosti učenja o organskoj proizvodnji iz prve ruke, osobnim značajem i elementom iskrenosti isku- 
stva (McIntosh i Bonnemann, 2006). Choo i Jamal (2009) istražuju WWOOFing kao novi oblik ekoturizma na organskim farmama u Južnoj Koreji - eko-organski seoski turizam, koji, vodeći se načelima ekoturizma, može predstavljati vodeću paradigmu održivosti za male organske farmere koji se uključuju u turizam. Yamamoto i Engelsted (2014) istražuju WWOOFing kao oblik seoskog i volonterskog turizma u SAD-u - volonterski organski seoski turizam. Kao oblik seoskog turizma WWOOFing je obilježen članstvom malih nezavisnih farmera, ekološki osviještenim praksama i izrazitom autentičnošću turističkog iskustva. Kao oblik volonterskog turizma, WWOOFing je obilježen ravnopravnom raspodjelom moći i izravnom vezom između volontera i domaćina te ograničenom ulogom posredničkih nevladinih organizacija, za razliku od „tipičnog" volonterskog turizma u kojem je narušena ravnopravna raspodjela moći, odnosno zamjetna značajna uloga posredničkih nevladinih organizacija koje volonterski rad najčešće usmjeravaju na razvoj i / ili obnovu okoliša (Yamamoto i Engelsted, 2014). Obilježja volonterskih turista kao onih koji, na osobnoj razini, pokazuju interes za putovanjima, novim i autentičnim iskustvima te osobnim razvojem, odnosno intenzivnijom interakcijom s lokalnim stanovništvom i težnju donošenju pozitivnih promjena u prostoru i društvu koje posjećuju, na široj društvenoj razini (Alvarez, 2012), uvelike se poklapaju s obilježjima WWOOFera. Riječ je o pojedincima koji traže turistička iskustva korisna ne samo za osobni razvoj, već i prirodni, društveni i gospodarski kontekst u koji su privremeno uključeni. Iskustvo WWOOFinga nerijetko se opisuje kao autentičnije, iskrenije i osobno značajnije od turističkog iskustva (Nimmo, 2001; McIntosh i Bonnemann, 2006; Deville, 2011; Deville i Wearing, 2013), prvenstveno zbog njegova istaknutog kulturnog, nenovčanog i dekomodificirajućeg aspekta (Deville i sur., 2015a). Upravo stoga istraživanje WWOOFinga kao oblika turizma nerijetko kritiziraju članovi pokreta WWOOF koji na turizam gledaju prvenstveno kao na djelatnost koja generira profit (Alvarez, 2012; Kosnik, 2013). Mnogi WWOOFeri i njihovi domaćini ističu svoju različitost od konvencionalnih turista i turističkih praksi, a direktori nacionalnih organizacija WWOOFa distanciraju se od pružatelja turističkih usluga (Kosnik, 2013). Tako primjerice domaćini $W W O O F$ a na Novom Zelandu ističu kako sebe ne smatraju turističkim poduzetnicima koji nude smještaj i „glumljenu“ autentičnost koja obilježava konvencionalni seoski turizam (Mcintosh i Campbell, 2001). Domaćini WWOOFa i WWOOF-eri na Havajima odbijaju identifikaciju s turizmom smatrajući kako WWO$O F$ prvenstveno predstavlja alternativni oblik ekonomske razmjene (Mostafanezhad, 2015). S druge strane, domaćini WWOOFa u SAD-u uglavnom prepoznaju WWOOFing kao oblik turizma ističući kako i sami nerijetko potiču WWOOFere na turističko ponašanje - odlazak na izlete u okolicu, sudjelovanje u lokalnim događanjima i interakciju s lokalnim stanovništvom (Terry, 2014). WWOOFing u Australiji i Novom Zelandu prerastao je u svjestan turistički projekt čiji je sekundarni cilj postalo udomaćivanje putnika, a primarni cilj još uvijek čini organska proizvodnja (Deville i Wearing, 2013;

4 Engl. eco-organic farm tourism

5 Engl. volunteer organic farm tourism 
McIntosh i Bonnemann, 2006; Mcintosh i Campbell, 2001). Deville i sur. (2015) skreću pozornost na sve izraženiji proces komodifikacije WWOOFinga kao posljedicu njegova pretvaranja u alternativno turističko iskustvo. Naime, suvremene turističke tokove obilježava pojava „tragača za iskustvom“ koji u sve većoj mjeri izbjegavaju „utabane staze masovnog turizma“ i tipičan turistički doživljaj koji se uz njega veže. WWOOFing se danas nalazi u svojevrsnoj borbi oblikovanja novog identiteta istovremeno nastojeći privući široku publiku i ne komercijalizirati se kao turistička djelatnost. Sve veća potražnja za WWOOFingom intenzivira tendenciju nadilaženja ideala organske poljoprivrede i održivosti, odnosno korištenje WWOOFinga prvenstveno kao sredstva jeftinijeg načina putovanja (Deville i sur., 2015b). Iako je, u skladu sa svojim idealima i ciljevima, WWOOFing u osnovi volonterske prirode i teži nenovčanoj razmjeni, u određenoj mjeri ipak generira turistički profit, poput troškova putovanja, jedno- / višednevnih izleta u okolicu ili suvenira.

Specifičnost WWOOFinga kao turističkog iskustva odraz je ideala i ciljeva pokreta WWOOF, a ogleda se u volonterskoj prirodi iskustva, sudjelovanju u poslovima na organskoj farmi, izrazitoj kulturnoj razmjeni s domaćinima i drugim WWOOFerima, naglašenoj edukativnoj komponenti usmjerenoj na usvajanje znanja o organskoj poljoprivredi i alternativnom / zelenom načinu života. $U$ uvodu je već istaknuto da se radna razmjena sastoji od sudjelovanja WWOOFera u svakodnevnim poslovima na farmi, pri čemu je naglasak na poslovima vezanim uz organsku proizvodnju, ali i drugim poslovima poput uređivanja i održavanja imanja ili kućanskih poslova. WWOOFeri u prosjeku dnevno rade 4-6 sati. Iako se temelji na radnoj razmjeni, u središtu iskustva WWOOFinga nalazi se kulturna razmjena o kojoj, prema Kosnik (2013), često ovisi uspjeh ovog pokreta. Intenzivna kulturna razmjena između domaćina i WWOOFera oblikuje se kroz dijeljenje obroka i krova nad glavom, zajedničko provođenje velikog dijela (slobodnog i radnog) vremena, zajednički odlazak na društvena događanja ili obiteljska okupljanja, pokazivanje interesa i dubinske rasprave o životu i načinima suočavanja s pozitivnim ili negativnim situacijama u kojima se WWOOFer i domaćin mogu zateći za vrijeme boravka WWOOFera na farmi.

WWOOFing je jedinstven zbog svoje vizije održive budućnosti proizašle iz osviještenosti o ekološkoj krizi koju može popraviti samo ljudski rad, stoga njegovi sudionici rade rame uz rame kako bi dali vlastiti doprinos rješavanju tog problema. Domaćini $W W O-$ $O F a$ dijele slične stavove prema prirodi, ljubav prema životu u ruralnim područjima, težnju za održivim korištenjem resursa, brigu za zdravlje i prehranu te antikonzumerističke i antikapitalističke ideale (Alvarez, 2012) koje nastoje prenijeti na volontere.

Spomenuta obilježja WWOOFinga čine temelj njegova transformativnog potencijala. WWOOFing potiče vrlo intenzivnu kulturnu razmjenu koja je prepoznata kao ključni preduvjet transformacije pojedinca (Reisinger, 2013b). On orijentira, educira i transformira WWOOFera vezano uz teoriju održive poljoprivrede i načina života, uz poticanje

6 Engl. experience seekers 
na aktivan doprinos WWOOFera radom na organskoj farmi (Deville i Wearing, 2013). Istraživanje provedeno u Australiji pokazalo je kako su čak i oni WWOOFeri čiji je primarni motiv za sudjelovanje u WWOOFingu činila želja za upoznavanjem australskog stanovništva, kulture i prostora s vremenom došli u kontakt s temeljnim vrijednostima i ciljevima $W W O O F a$, nerijetko i sami prihvaćajući održive prakse svojih domaćina (Deville i sur., 2015a). Niz dosadašnjih istraživanja utvrdio je pojedine ishode transformacije pojedinca kroz WWOOFing koji se ogledaju na osobnoj i široj društvenoj razini (Deville i Wearing, 2013; Deville i sur., 2015a; Miller i Mair, 2015; McIntosh i Bonnemann, 2006):

- povećana potrošnja organski proizvedene hrane i podrška organskom pokretu,

- bolje razumijevanje problema ekološke održivosti,

- prihvaćanje paradigme $W W O O F a$, odnosno ekocentrične paradigme općenito,

- promjena načina života - zaokret prema održivosti,

- želja za uključivanjem u pokret WWOOF u ulozi domaćina (a ne samo WWOOFera),

- osviještenost o „realnosti seoskog života“ - utjecaju vremenskih prilika, prirodnih katastrofa i političke moći,

- poticanje želje za vrtlarenjem i / ili radom na farmi,

- stjecanje novih znanja i vještina (praktičnih i osobnih),

- razvoj otvorenosti, optimizma, tolerancije i povjerenja u druge ljude,

- razvoj međukulturnog dijaloga i nadilaženje negativnih kulturnih stereotipa.

Wearing (2015) ističe kako domaćini WWOOFa često prepoznaju transformativni potencijal WWOOFinga, stoga svoju ulogu domaćina vide kao oblik društvenog aktivizma (Mostafanezhad, 2015). Nadaju se da će volonteri sa sobom ponijeti i u svakodnevnom životu primijeniti naučeno, kupovati lokalno i organsko, imati vlastiti vrt i proširiti svijest o „zelenom“ načinu života (Kosnik, 2013). Očekuje se da će WWOOFing kao pokret i poseban oblik volonterskog ekoturizma i dalje rasti, $s$ obzirom na to da je, svojom vizijom i tipom iskustva koje nudi, u skladu s posljednjim trendovima na turističkom tržištu, ali i aktualnom promjenom šire, društvene paradigme bitnim dijelom usmjerene upravo na nadilaženje konzumerističkih i kapitalističkih ideala koji se nalazi u srži dominantne neoliberalne paradigme.

\section{POJAVA, RAZVOJ I OBILJEŽJA WWOOFINGA U HRVATSKOJ}

Pojavu WWOOFinga u Hrvatskoj, odnosno prvo članstvo hrvatskog domaćina u organizaciji $W W O O F a$, možemo pratiti od 2004. godine. Prema podacima dostupnim na stranici nezavisnih organizacija WWOOFa, u organizaciju WWOOFa u razdoblju od 2004. do 2012. godine učlanilo se svega nekoliko domaćina, a nakon 2012. godine zamjetan je značajniji porast broja domaćina, uz maksimum zabilježen 2015. godine kad se u organizaciju WWOOFa učlanilo čak 13 novih domaćina (sl. 2). Danas je u organizaciju WWOOFa uključeno 36 domaćina, no još uvijek nije osnovana nacionalna organizacija $W W O O F a$, stoga Hrvatska i dalje spada pod nezavisne organizacije WWOOFa. 


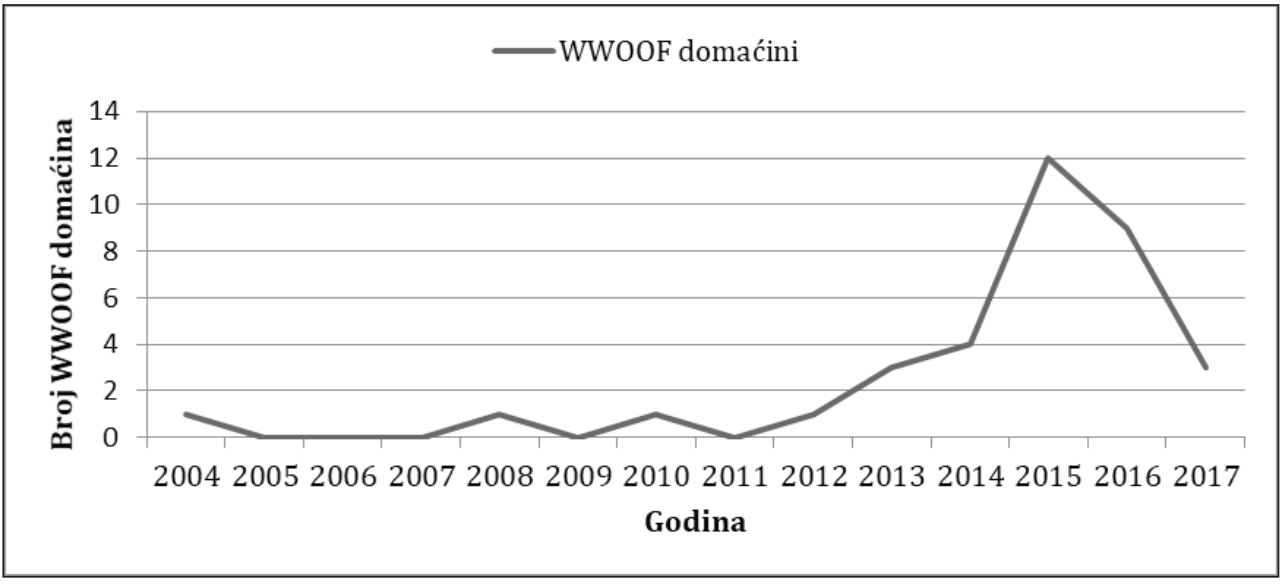

Izvor: WWOOF Croatia, 2017

Slika 2. Kretanje broja domaćina WWOOFa u Hrvatskoj od 01. siječnja 2004. do 31. siječnja 2017. godine

$\mathrm{Na}$ priloženoj karti prikazana je geografska rasprostranjenost domaćina $W W O O F a \mathrm{u}$ Hrvatskoj (sl.3). Vidljivo je kako su domaćini WWOOFa, odnosno njihove organske farme, disperzno razmješteni diljem čitave Hrvatske, uz nešto veću koncentraciju u Istarskoj županiji. Zanimljivo je istaknuti kako se upravo u Istarskoj županiji pojavio prvi domaćin $W W O O F a$, a čak 5 od spomenutih 13 novih domaćina u organizaciji WWOOFa 2015. godine činili su upravo oni iz Istarske županije. Organske farme uglavnom su smještene u ruralnom prostoru u blizini većih gradova koji nerijetko čine ključna tržišta za njihove organske proizvode.

Analizom podataka dostupnih na stranici nacionalnih organizacija WWOOFa (WWOOF Croatia, 2017) utvrđen je profil domaćina WWOOFa i njihove ponude u Hrvatskoj. Domaćine najčešće čine osobe srednje dobi koje su samci ili imaju obitelj te posjeduju vlastito zemljište na kojem imaju organsku farmu. Farma nije nužno glavni izvor prihoda; nerijetko su jedan ili više radno aktivnih članova kućanstva zaposleni izvan farme ili ostvaruju dodatne prihode kroz obrtništvo, umjetnički rad ili vođenje edukativnih programa. Dio domaćina $W W O O F a$ na farmi boravi isključivo u vrijeme ljetne sezone radova. Ponuda domaćina WWOOFa razlikuje se od farme do farme, što se primjerice očituje u (očekivanoj) duljini boravka, tipu smještaja i / ili poslova, no u određenoj je mjeri usklađena s kriterijima koje je utvrdila nacionalna organizacija $W W O O F a$, pri čemu je ključni kriterij uključenost u organsku proizvodnju. Očekivana prosječna duljina boravka WWOOFera na pojedinoj farmi iznosi od dva tjedna do dva mjeseca, uz maksimalnu očekivanu duljinu boravka od čak devet mjeseci. Tip smještaja varira od spavanja u šatorima, kamp-kućicama, gostinjskoj kući ili kući samog domaćina. Opremljenost sanitarnim čvorom, tušem, grijanjem, štednjakom pa čak i namještajem također varira od farme do farme. Poslovi koji se nude uglavnom se odnose na rad u vrtu ili voćnjaku, rad sa životinjama, održavanje imanja i kućanske poslove. Tip posla odraz je i geografskog konteksta organske farme; duž 
Jadranske obale i na otocima moguće je sudjelovati u radovima u masliniku ili vinogradu, uzgoju ljekovitog bilja (poput lavande), mandarina i orašastih plodova, dok je u kontinentalnoj Hrvatskoj naglasak na poslovima poput uzgoja voća i povrća, radu sa životinjama (kokoši, svinje, konji), proizvodnji domaće hrane (sir i mlijeko, džem, ajvar, rakija, vino) i održavanju šuma. Osim poslova izravno vezanih uz organsku proizvodnju, nude se i poslovi poput restauracije drvenih kuća, gradnje kuća od slame i pletenih ograda, staklenika i zelenih krovova, proširenja prostora za kampiranje, pomoć u umjetničkom radu, izrada skulptura, slika i namještaja od drveta. Dio domaćina WWOOFa izravno je uključen u turizam, stoga WWOOFeri imaju prilike sudjelovati u organizaciji pojedinih manifestacija (festivali, biciklističke ture) ili raditi na očuvanju i promociji kulturne baštine i turističkog identiteta pojedinog mjesta, $s$ gostima i / ili u restoranu. Povezivanje s turizmom, domaćinima osigurava dodatni izvor prihoda i novo tržište za prodaju vlastitih proizvoda.

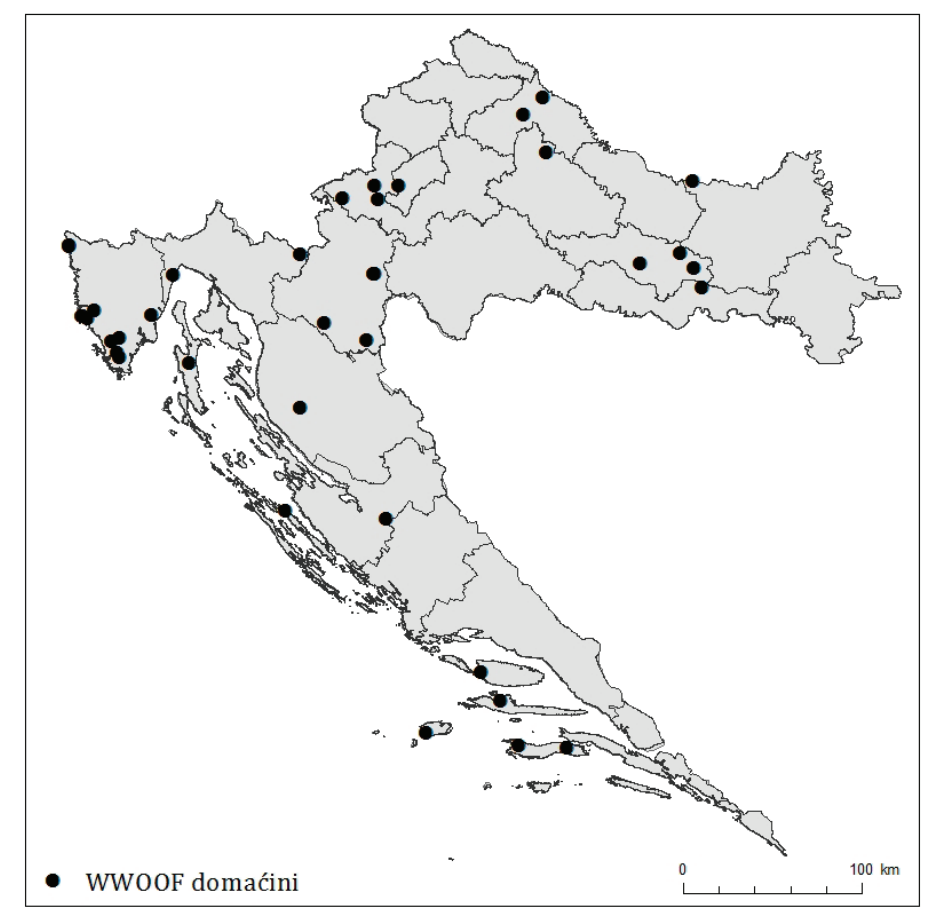

Izvor: WWOOF Croatia, 2017

Slika 3. Geografska rasprostranjenost domaćina WWOOFa u Hrvatskoj

\section{MOTIVACIJA DOMAĆINA WWOOFA}

Motivaciju domaćina za uključivanje u WWOOF moguće je svesti na tri kategorije: osiguravanje dodatne (volonterske) pomoći na farmi, upoznavanje ljudi / kultura iz različitih dijelova svijeta te širenje znanja o održivom načinu života i organskoj poljopri- 
vredi. Ovakve rezultate potvrdio je niz dosadašnjih istraživanja o motivaciji domaćina WWOOFa (Alvarez, 2012; Deville, 2015; McIntosh i Bonnemann, 2006; Mcintosh i Campbell, 2001; Mostafanezhad, 2015; Terry, 2014; Yamamoto i Engelsted, 2014).

Osiguravanje dodatne volonterske pomoći na farmi jedan je od najčešćih razloga za uključivanje u WWOOF (Alvarez, 2012; McIntosh i Bonnemann, 2006; Terry, 2014). Organska proizvodnja, koja se nalazi u središtu pokreta WWOOF, iziskuje veća ulaganja (ljudske) radne snage od konvencionalne proizvodnje koja uključuje korištenje kemijskih sredstava za zaštitu bilja. Potreba za zapošljavanjem dodatne radne snage nerijetko izaziva financijske poteškoće: „To je puno zemlje i jako puno posla za jednu osobu, a jednostavno nemam toliko velike prihode da mogu zaposliti stalne radnike. Tako mi je prijateljica sugerirala da se probam umrežiti $u$ WWOOF jer je smatrala da bi mnogi mladi bili zainteresirani za rad na mojem imanju u zamjenu za smjestaj. Prijavila sam se, moja prijava je prihvaćena i tako je sve počelo. "Ispitanik A) (Tomljenović i sur., 2015:24) Dodatnu prednost volonterske pomoći čine prethodne vještine, znanja i volja volontera. Volonteri ponekad posjeduju znanja i vještine vrlo korisne za organsku farmu i same domaćine koja prenose na njih ostavljajući tako dugoročni pozitivni utjecaj: „Počeli smo prije godinu dana jer nam se svidio taj princip gdje ti ponudiš nešto - smještaj, hranu, ali i dobiješ nešto za uzvrat - rad na imanju. Isto tako, trebala nam je i pomoć oko imanja jer smo sami u tome i mladi smo pa trebamo i ljude zbog iskustva. "(Ispitanik C) (Tomljenović i sur., 2015:31).

Upoznavanje ljudi i kultura iz različitih dijelova svijeta čini drugi bitni motiv domaćina za uključivanje u WWOOF. Domaćini nerijetko na WWOOFere gledaju kao „pogled u svijet“ - strategiju pomoću koje, s jedne strane, uče o različitim kulturama i prostorima te, $s$ druge strane, šire vlastitu društvenu mrežu povezujući se s ljudima koji dijele iste ili slične ideale, vrijednosti i stavove: „Glavni razlog što smo krenuli s WWOOFingom želja je za upoznavanjem mladih ljudi iz raznih dijelova svijeta. Isto tako i mi, moja žena i ja, htjeli bismo jednoga dana putovati na taj način pa će nam ti kontakti koje održavamo sa svojim posjetiteljima biti korisni" (Ispitanik B) (Tomljenović i sur., 2015:28). Pojedini domaćini pritom ističu i dobrobit svoje djece: „Imamo djecu pa smo smatrali kako bi $i$ za njih bilo dobro da upoznaju WWOOFere i provode vrijeme s njima, da upoznaju druge kulture" (Ispitanik D) (Tomljenović i sur., 2015:35). Udomaćivanje WWOOFera može služiti i kao strategija borbe protiv osamljenosti i izolacije seoskog života: „Na taj se način i spajamo sa svijetom jer smo tamo [na organskoj farmi, op.a.] dosta izolirani. "(Ispitanik C) (Tomljenović i sur., 2015:31).

Domaćini WWOOFa u značajnoj su mjeri motivirani širenjem znanja o održivom načinu života i organskoj poljoprivredi: „Naš je ključni cilj poučiti ljude o permakulturi, o održivom načinu života, o organskoj poljoprivredi...Mi zaista pokušavamo spasiti svijet!"(Ispitanik D) (Tomljenović i sur., 2015:35). Promocija ekološke osviještenosti i održivosti zajednička je svim domaćinima WWOOFa koji vlastitim primjerom i omogućivanjem aktivnog uključivanja WWOOFera u proces organske proizvodnje i život na farmi nastoje prenijeti svoja znanja i vještine, ali i potaknuti (trajne) promjene stavova, vrijednosti i ponašanja pojedinaca: „Organska proizvodnja hrane sama po sebi spada u 
ekološki održivu poljoprivredu tako da bih rekla da moja farma apsolutno promovira ekološku osviještenost. Takoder pokazujem gostima da se može uzgajati organska hrana za vlastite potrebe i opet ne biti u dugovima, tj. biti financijski neovisan. "(Ispitanik A) (Tomljenović i sur., 2015:25); „Da, radi se o organskom uzgoju voća i povrća. Uz to pokuśavamo uvesti sistem permakulture na cijelom imanju" (Ispitanik C) (Tomljenović i sur., 2015:32).

\section{PROFIL I DOSADAŠNJA ISKUSTVA S WWOOFERIMA}

Domaćini $W W O O F a$ koji su sudjelovali u istraživanju kroz proteklih su 3-5 godina ugostili oko stotinjak WWOOFera iz čitavog svijeta. Na temelju njihovih odgovora moguće je izdvojiti profil tipičnog WWOOFera koji posjećuje Hrvatsku: mlada, visokoobrazovana osoba, srednje i više klase, uglavnom europskog ili sjevernoameričkog podrijetla koja u Hrvatsku najčešće dolazi samostalno, ponekad s prijateljima i / ili partnerom: „Radi se o mladim ljudima koji studiraju ili se tek spremaju otici na fakultet." (Ispitanik C) (Tomljenović i sur., 2015:31); „Rekla bih da se radi o srednjoj i višoj srednjoj klasi...Najčesće dolaze iz razvijenih zapadnih zemalja. Konkretno najviše iz SAD-a, Kanade, UK-a i Francuske. Medutim, mogu reći da sam imala goste iz stvarno raznih dijelova svijeta. " (Ispitanik A) (Tomljenović i sur., 2015:24); „Neki su dolazili sami, a neki s prijateljima ili partnerima" (Ispitanik B) (Tomljenović i sur., 2015:28).

Potražnja za WWOOFingom ravnomjerno je raspoređena tijekom cijele godine, uz nešto veću potražnju tijekom ljetne turističke sezone: „Ravnomjerno su rasporedeni tijekom cijele godine. Svaki mjesec mi se javi barem jedan kandidat. Primijetila sam da ih nešto više dolazi u 7. mjesecu, no njih bih opisala kao nešto tipičnije turiste." (Ispitanik A) (Tomljenović i sur., 2015:25); "Javljaju se stvarno kroz cijelu godinu. Možda malo više u proljeće $i$ na ljeto, ali ionako nema puno posla na imanju preko zime. Mi ih primamo kada je potrebno obaviti nekakve poslove na imanju - znači kada im možemo ponuditi neke aktivnosti“ (Ispitanik C) (Tomljenović i sur., 2015:32).

Kazivači ističu kako se motivacija WWOOFera za sudjelovanje u WWOOFingu uvelike razlikuje od pojedinca do pojedinca. Ipak, moguće je izdvojiti tri ključne kategorije motiva: želja za učenjem i aktivnim sudjelovanjem u organskoj proizvodnji i alternativnom „zelenom“ načinu života; bijeg od svakodnevnice i potraga za novim i autentičnim iskustvima; mogućnost jeftinijeg načina putovanja i boravka u destinaciji. Dio WWOOFera dijeli općenite vrijednosti i stavove pokreta $W W O O F$, stoga njihov primarni motiv za sudjelovanjem u WWOOFu čini želja za učenjem i aktivnim sudjelovanjem u organskoj proizvodnji te alternativnom načinu života. Izrazita osviještenost postmodernog društva o negativnim učincima čovjeka na okoliš, odnosno potrebi održivog razvoja i upravljanja prostorom, dovodi do preispitivanja dosadašnjeg načina života i traženja alternativnih načina postizanja sklada između čovjeka i prirode, što se nerijetko postiže upravo kroz WWOOFing: „Mladi ljudi uglavnom dolaze jer traže nekakve alternativne puteve, žele vidjeti je li moguće skladno živjeti sa zemljom i od zemlje. Okrenuti su prirodi, kreativni su. Neki žele i sami pokrenuti održivo gospodarstvo" (Ispitanik A) (Tomljenović i sur., 2015:24). Bijeg od svakodnevnice i potraga za novim, alternativnim i autentičnim isku- 
stvima jedni su od ključnih turističkih motiva današnjice. Značajan broj WWOOFera čine poslovni ljudi koji bježe od stresa, (pasivnog) uredskog posla i užurbane gradske svakodnevnice nastojeći svoju dokolicu provesti aktivno u mirnoj ruralnoj sredini: „... [WWOOFer, op.a.] radi jedan vrlo stresan posao vezan uz trgovinu i medunarodne odnose $i$ on jedva čeka da se makne iz te gužve poslovnog svijeta i dode raditi na polje" (Ispitanik A) (Tomljenović i sur., 2015:24) ili mladi ljudi koji tragaju za novim iskustvima: „Čini nam se da su naši mladi gosti dolazili više po neko novo iskustvo, uz jeftin način putovanja $i$ boravka u stranoj zemlji“ (Ispitanik C) (Tomljenović i sur., 2015:31); „Neki gosti žele promijeniti životni ritam pa se odlučuju za WWOOF. Imali smo jedan mladi par iz Engleske koji su krenuli putovati $i$ volontirati po svijetu nakon što su $i$ ona $i$ on dali otkaze na svojim poslovima u Londonu" (Ispitanik B) (Tomljenović i sur., 2015:28). Ovakve rezultate u značajnoj je mjeri potvrdio niz dosadašnjih istraživanja (Kosnik, 2013; McIntosh i Bonnemann, 2006; Mcintosh i Campbell, 2001). Pružanje mogućnosti jeftinijeg načina putovanja i boravka u destinaciji u velikoj je mjeri odraz jednog od temeljnih načela WWOOFa - nenovčane razmjene. U zamjenu za rad na organskoj farmi WWOOFeru je osiguran smještaj i hrana, stoga njegove jedine troškove čine putni troškovi te troškovi koji izlaze iz okvira smještaja i hrane - odlazak na izlete, društvena i kulturna događanja, kupovina suvenira i sl.

Dosadašnja iskustva s WWOOFerima u značajnoj su mjeri pozitivna: „Odlična. Rekao bih savršena. Nikada nismo imali niti jedan problem s gostima "(Ispitanik B) (Tomljenović i sur., 2015:28); „Šarena. Neki su bili odlični. Toliko su mi bili divni da bih ih posvojila kao sina ili kćer" (Ispitanik A) (Tomljenović i sur., 2015:24). WWOOFeri pokazuju izrazit interes za učenjem i radom na organskoj farmi, kulturnom razmjenom s domaćinima i drugim WWOOFerima te upoznavanjem lokalne kulture, stanovništva i prostora: „Da, pokazuju [interes, op.a.], naravno. Uvijek im ispričamo sve o mjestu u kojem živimo, ljudima oko nas te ih, ako nam se svide, upoznajemo sa svojim prijateljima i susjedima, vodimo na izlete..." (Ispitanik D) (Tomljenović i sur., 2015:35); „Da, mogu reći da im je svima bilo zanimljivo sve što bismo im pokazali. Takoder, odlazili su i na izlete u druge krajeve Hrvatske, npr. Varaždin, Zadar" (Ispitanik B) (Tomljenović i sur., 2015:28). Interes za interakciju s WWOOFerima ne pokazuju samo domaćini $W W O O F a$, već i ostali članovi lokalne zajednice koji su prepoznali WWOOFing kao kvalitetan projekt. Njihov primarni motiv za kulturnu razmjenu $s$ WWOOFerima isti je kao kod domaćina WWOOFa - upoznavanje ljudi i kultura iz različitih dijelova svijeta: „Odlično smo prihvaćeni, naši se susjedi dolaze upoznati s našim gostima. Mladi gosti iz drugih dijelova svijeta su rijetkost ovdje pa su susjedima oni jako zanimljivi. Ne znam koliko ovaj naš posao pridonosi boljitku lokalne zajednice, ali stanovnici sela imaju priliku upoznati nove ljude $i$ to im je jako drago. "(Ispitanik B) (Tomljenović i sur., 2015:29); Upravo stoga, često provode vrijeme s njima: „Susjedi mi pomažu jako puno s posjetiteljima i u radu na samoj farmi. Jako im je drago da mogu popričati sa strancima iz raznih dijelova svijeta, a $i$ WWOFerima je drago upoznati i druge stanovnike u selu. Susjedi su se dobrovoljno uključili u projekt na način da ugošcuju WWOOFere na večerama te ih vode u izlaske, izlete, u Zagreb da malo vide grad i tako" (Ispitanik A) (Tomljenović i sur., 2015:29). Zabilježeno je i nekoliko nega- 
tivnih iskustava s WWOOFerima koja su nerijetko odraz nejasno definiranih očekivanja domaćina, odnosno želja i potreba WWOOFera, što rezultira nesporazumom, a ponekad i ranijim odlaskom WWOOFera s farme: „Imali smo mnogo pozitivnih iskustava, ali imala sam i nekoliko katastrofa zbog nejasne komunikacije. Čak smo imali situaciju u kojoj smo bili prisiljeni dvoje ljudi poslati kući." (Ispitanik D) (Tomljenović i sur., 2015:35). Negativna iskustva vežu se i uz nedostatak potrebnih znanja i vještina WWOOFera za rad na organskoj farmi: „Problem je bio što od tih četvero gostiju koji su do sad bili kod nas troje nije imalo nikakvog iskustva u takvom tipu posla (rad u prirodi ili na selu) i cijeli život su proveli u gradu. Oni bi pokazivali volju da pokušaju nešto obaviti, ali jednostavno nisu imali dovoljno znanja te nisu bili spremni do kraja odraditi postao stavljen pred njih" (Ispitanik C) (Tomljenović i sur., 2015:31); „Naravno, bilo je i nekih lošijih iskustava pa sam tako neke WWOOFere poslala kući. Gledajte, ja imam vrlo jasne zahtjeve koje moji gosti moraju zadovoljiti. Rad na polju iziskuje velik angažman i odredene vještine te nije baš za svakoga" (Ispitanik A) (Tomljenović i sur., 2015:24). Kako bi spriječili negativna iskustva, domaćini provode intervjue s WWOOFerima kroz koje dogovaraju detalje razmjene, opisuju trenutnu ponudu poslova i vještine koje su potrebne za njihovo provođenje te nastoje utvrditi motivaciju WWOOFera za sudjelovanjem u WWOOFingu: „Oni nama pošalju upit i nekakvo pismo o sebi. Pokušavamo procijeniti po načinu pisanja, po njihovim interesima, prijašnjim iskustvima. Naravno, teško je samo na temelju takve prijave izabrati dobrog kandidata" (Ispitanik C) (Tomljenović i sur., 2015:32). Minimalna duljina boravka često predstavlja strategiju osiguravanja dovoljnog vremena za stjecanje potrebnih vještina: „Ja tražim da se ostane minimalno dva tjedna jer mnogi provedu prvi tjedan dana učeći kako raditi na polju i upoznajući se sokolinom. "(Ispitanik A) (Tomljenović i sur., 2015:25), odnosno strategiju eliminiranja onih WWOOFera koji su vođeni prvenstveno turističkom motivacijom: "Rekla bih da je većina mojih gostiju bila vrlo angažirana, ali uvijek ima i onih koji su manje zainteresirani. Njih možete prepoznati vrlo rano jer obično ne žele ostati dulje od dva tjedna, a neki već imaju isplanirano cijelo putovanje po Hrvatskoj" (Ispitanik A) (Tomljenović i sur., 2015:25). Domaćini smatraju kako WWOOFere koje motiviraju prvenstveno mogućnost jeftinijeg načina putovanja i boravka u destinaciji obilježava manja zainteresiranost i angažman: „Obično nastojimo izbjeći one koji žele jeftin odmor jer zaista želimo udomaćiti ljude koji su motivirani i žele naučiti o svemu što nudimo"(Ispitanik D) (Tomljenović i sur., 2015:36).

\section{USPOREDBA WWOOFINGA S KONVENCIONALNIM I TRANSFORMATIVNIM TURIZMOM}

Domaćini WWOOFa istaknuli su nekoliko različitosti WWOOFinga od konvencionalnog turizma koje su prvenstveno vezane uz temeljne vrijednosti i ciljeve pokreta WWOOF, odnosno naglasak na ekološku osviještenost, učenje i aktivno provođenje slobodnog vremena: „Veoma su osviješteni o okolišu, o Zemlji, o onome što uzimaju od Zemlje. Oni stvarno žele spasiti planet. Mislim da tipični turisti nemaju takve stavove... Ja mislim da je WWOOF potpuno drugačija priča, nije za obične turiste koji idu na obalu 
samo kako bi se opustili i zabavili, ovdje je zapravo naglasak na učenju. Ja bih apsolutno išla na WWOOFing da mi je opet 20-25 godina. To je izvrsna prilika za jeftino putovanje i učenje“ (Ispitanik D) (Tomljenović i sur., 2015:35); „Primjetio sam kod svih da su puno više ekološki osviješteni od Hrvata, a što se tiče razlike u odnosu na klasične turiste, mislim da se razlikuju već samim tim što su WWOOFeri. Traže rad i aktivnosti, a ne odmor" (Ispitanik B) (Tomljenović i sur., 2015:28); „Razlikuju se od klasičnih turista. Nisu zainteresirani za paket aranžmane. Žele ostati na jednom mjestu duže vremena da bi ga bolje upoznali. Pokazuju interes za lokalnu zajednicu i žele upoznati kulturu i običaje"(Ispitanik A) (Tomljenović i sur., 2015:25). U najvećoj su se mjeri složili s tvrdnjom da WWOOFing zaista jest jedan od specifičnih oblika turizma navodeći agroturizam, ekoturizam, volonterski turizam i / ili edukativni turizam: „Pa rekla bih da može spadati pod turizam, ali turizam u jako sirokom smislu. To bi onda bila vrsta agroturizma. Ja sam turizam uvijek tumačila kao dokolicu, a ovo je onda ipak puno aktivniji tip turizma" (Ispitanik A) (Tomljenović i sur., 2015:27); „Mi osobno bismo se jednog dana htjeli svrstati u okviru aktivnog, edukativnog ili eko-turizma (ili kombinacija sve troje). Edukativni i ekoturizam bio bi zbog toga što planiramo organizirati i razne radionice koje bi se odnosile na život u skladu s prirodom i slično" (Ispitanik C) (Tomljenović i sur., 2015:33); „Da, definitivno! To je jeftin način putovanja i učenja, no ne znam koji bi oblik bio. ... Agroturizam!“ (Ispitanik D) (Tomljenović i sur., 2015:38). Tek jedan domaćin WWOOFa smatra kako se WWOOFing ne može smatrati oblikom turizma: "Jednostavno ne radi se o djelatnosti koja generira profit, više o volontiranju“ "(Ispitanik B) (Tomljenović i sur., 2015:30). Iako isprva neupućeni u koncept transformativnog turizma, domaćini $W W O O F a$ su, nakon što su im pojašnjena njegova osnovna načela i ciljevi, u značajnoj mjeri prepoznali WWOOFing kao oblik transformativnog turizma: „Da. Definitivno prepoznajem svoju ponudu u opisu takvog [transformativnog] turizma“ (Ispitanik A) (Tomljenović i sur., 2015:27); „Da i mislili smo da bi taj transformativni turizam mogao imati takve efekte i primijetili smo da su neki turisti, ne nužno naši gosti, koji su otišli na takva putovanja stvarno duboko taknuti iskustvima i pišu o njima na blogovima, društvenim mrežama" (Ispitanik C) (Tomljenović i sur., 2015:33). Samo je jedan kazivač istaknuo suprotno: „Pa ne mogu baš reći da prepoznajem sebe ili svoje goste u tom opisu" (Ispitanik B) (Tomljenović i sur., 2015:30). Ipak, kroz svoje odgovore na niz prethodno postavljenih pitanja tijekom dubinskih intervjua, svi su domaćini (svjesno ili nesvjesno) pokazali kako i sami dijele i prakticiraju vrijednosti i ciljeve pokreta WWOOF, nastoje prenijeti što više vlastitih znanja i vještina na WWOOFere, intenzivirati kulturnu razmjenu i pružiti im alternativno i autentično iskustvo kreirajući tako vrlo bitne preduvjete za transformaciju WWOOFera.

Domaćini WWOOFa nerijetko, kroz proces neformalne kulturne razmjene, promoviraju Hrvatsku i potiču WWOOFere na turističku aktivnost: „Uvijek kažemo kako je ovdje odlično, kako su ljudi odlični, kako zaista živimo održivim načinom života. Uvijek kažemo da je Hrvatska odlična zemlja - otvorena kulturama, nudi mnogo.. "(Ispitanik D) (Tomljenović i sur., 2015:37); „Mislim da projekt promovira i samo područje, ali i cijelu Hrvatsku. Ja, sama, nemam puno vremena da ih vodim po raznim dogadanjima, ali svakako im uvijek preporučujem da odu na lokalne manifestacije, da posjete zanimljivosti koje su im u blizini, 
na primjer Andautonija "(Ispitanik A) (Tomljenović i sur., 2015:26). Trenutno ne postoji suradnja s hrvatskim turističkim sektorom, a jedino sredstvo promocije WWOOFinga jest sam portal WWOOFa: „Ne postoji nikakva suradnja u smislu promocije. Mecutim, moram priznati da ni sama nisam pokazivala inicijativu u tom smjeru jer jednostavno imam puno posla i malo vremena. Jedina promocija je zapravo sam portal WWOOFa" (Ispitanik A) (Tomljenović i sur., 2015:26). Ipak, neki je domaćini WWOOFa planiraju u bližoj budućnosti: „Za sada ne postoji nikakva suradnja osim one u sklopu organizacije WWOOFa. U budućnosti mislimo kontaktirati turističku zajednicu Bjelovarsko-bilogorske županije u svrhu neke promocije. "(Ispitanik B) (Tomljenović i sur., 2015:30) te općenito ističu potrebu njegove bolje promocije: „WWOOFing je novi koncept u Hrvatskoj i treba ga promovirati u medijima. "(Ispitanik A) (Tomljenović i sur., 2015:27). Jedan od domaćina WWOOFa istaknuo je zakonske probleme prilikom osnivanja hrvatske podružnice WWOOFa koji bi u bližoj budućnosti trebali biti riješeni: „Svaki put kada bismo mi ili drugi WWOOFovci imali nekakvu inicijativu (kao što je bio pokušaj organiziranja udruge WWOOFa u Hrvatskoj) naišli bismo na zakonske prepreke. "(Ispitanik C) (Tomljenović i sur., 2015:33).

\section{ZAKLJUČAK}

Ključni ciljevi ovog rada bili su stjecanje početnog uvida u obilježja WWOOFinga u Hrvatskoj te istraživanje WWOOFinga u kontekstu transformativnog turizma (iz perspektive domaćina $W W O O F a$ ). Istraživanje je pokazalo kako primarnu motivaciju domaćina za uključivanje u WWOOF čini osiguravanje dodatne (volonterske) pomoći na farmi, upoznavanje ljudi / kultura iz različitih dijelova svijeta te širenje znanja o održivom načinu života i organskoj poljoprivredi. S druge strane, primarnu motivaciju WWOOFera za sudjelovanje u WWOOFingu čini želja za učenjem i aktivnim sudjelovanjem u organskoj proizvodnji i alternativnom „zelenom“ načinu života, bijeg od svakodnevnice i potraga za novim i autentičnim iskustvima, mogućnost jeftinijeg načina putovanja i boravka u destinaciji. Tipičan WWOOFer koji posjećuje Hrvatsku mlad je (18-35 godina), visokoobrazovan, srednje i više klase, uglavnom europskog ili sjevernoameričkog podrijetla. Dosadašnja iskustva s WWOOFerima u značajnoj su mjeri pozitivna, dok su ona negativna najčešće odraz nedostatka komunikacije između domaćina i WWOOFera. Domaćini WWOOFa jasno su istaknuli različitost WWOOFinga od konvencionalnog turizma koja se prvenstveno temelji na vrijednostima i ciljevima cjelokupnog pokreta WWOOF. Utvrđeno je kako WWOOFing predstavlja transformativni oblik turizma koji doprinosi ostvarenju vizije održivog svijeta mira i sloge kroz iskustvo intenzivne radne i kulturne razmjene, izravno uključivanje u svakodnevnicu i živote domaćina te učenje o organskoj poljoprivredi i održivosti alternativnog načina života iz prve ruke.

Domaćini WWOOFa uključeni u ovo istraživanje istaknuli su određene potrebe daljnjeg razvoja WWOOFinga: suradnju s turističkim sektorom, promociju WWOOFinga $\mathrm{u}$ široj javnosti te osnivanje nacionalne organizacije WWOOFa u Hrvatskoj. Povezivanje 
$s$ turističkim sektorom i promocija WWOOFinga u široj javnosti smatraju se bitnim za širenje ideja i ideala pokreta $W W O O F$ na širu populaciju. Osnivanje nacionalne organizacije $W W O O F a$ u Hrvatskoj potencijalno bi rezultiralo brojnim pozitivnim ishodima - umrežavanjem i većom suradnjom WWOOFera, utvrđivanjem i usklađivanjem pravila i kriterija (za uključivanje u WWOOF na strani domaćina i WWOOFera, obilježja ponude i sl.), vođenjem statističkih podataka o obilježjima i kretanju broja WWOOFera, zajedničkoj promociji Hrvatske kao destinacije WWOOFinga. Činjenica da je WWOOFing relativno nova pojava u Hrvatskoj turističkom sektoru pruža jedinstvenu priliku planiranja i usmjeravanja njegova razvoja na put održivosti od samih početaka - priliku koju u današnjem svijetu ekspanzivnog i često „neuhvatljivog“ rasta turizma (hrvatski) turistički sektor rijetko ima. WWOOFing ima potencijal ojačavanja hrvatske ekonomske, društvene i ekološke održivosti, posebice u ruralnim područjima zahvaćenim izrazitim depopulacijskim procesima.

Daljnja istraživanja WWOOFinga u Hrvatskoj trebala bi obuhvatiti i perspektivu WWOOFera kako bismo stekli uvid u percepciju i stavove druge ključne strane koja sudjeluje u WWOOFingu, utvrdili sličnosti i razlike između njihove percepcije i percepcije domaćina $W W O O F a$ te identificirali sve prednosti i nedostatke aktualne ponude, odnosno potrebe i mogućnosti daljnjeg razvoja. U kontekstu transformativnog turizma također je potrebno obuhvatiti perspektivu domaćina - njihove stavove, vrijednosti i ponašanja prije, za vrijeme i nakon iskustva WWOOFinga, ali i produbiti istraživanje pogleda na život i sustav vrijednosti domaćina $W W O O F a$, principe kojima se vode u osobnom i profesionalnom životu te načine kojima i sami doprinose u ostvarenju održivog svijeta mira i sloge. Imajući na umu kako je kulturna razmjena nerijetko obostran proces, potrebno je istražiti da li i u kolikoj mjeri sudjelovanje u WWOOFingu transformira i same domaćine.

\section{ZAHVALE}

Ovaj se rad temelji na projektu „TRANS-TURIZAM: Integrirani pristup proučavanju transformativne uloge turizma u 21. stoljeću“ kojeg financira Hrvatska zaklada za znanost pod projektnim brojem 6164. 


\section{LITERATURA}

Alvarez, M. A. V. (2012). World Wide Opportunities on Organic Farms (WWOOF) Expectations of Hosts and Volunteers. Magistarski rad. Blindern: University of Oslo.

Ateljević, I. (2009). Transmodernity - remaking our (tourism) world? U: Tribe, J. (ur.), Philosophical Issues of Tourism (str. 278-300). Amsterdam: Elsevier Social Science Series

Ateljević, I. (2011). Transmodern Critical Tourism Studies: A call for hope and transformation. Revista Turismo em Analise special issue, 22(3): 497-515.

Ateljević, I. i Tomljenović, R. (2016). Triple T: Tourism, Transmodernity and Transformative Learning. Turističko poslovanje, 17: 25-31.

Choo, H. i Jamal, T. (2009). Tourism on organic farms in South Korea: a new form of ecotourism? Journal of Sustainable Tourism, 17(4): 431-454.

Deville, A. (2015). Transformation and the WWOOF Exchange: The Host experience. U: Reisinger, Y. (ur.), Transformational Tourism: Host Perspectives (str. 141-164). Wallingford: Centre for Agriculture and Bioscience International (CABI).

Deville, A. i Wearing, S. (2013). WWOOF-ing Tourists, Beaten Tracks and Transformational Paths. U: Reisinger, Y. (ur.), Transformational Tourism: Tourist Perspectives (str.151- 169). Wallingford: Centre for Agriculture and Bioscience International (CABI).

Deville, A., Wearing, S. i McDonald, M.(2015a). Tourism and Willing Workers on Organic Farms: a collision of two spaces in sustainable agriculture. Journal of Cleaner Production, 111: 421-429.

Deville, A., Wearing, S. i McDonald, M.(2015b). WWOOF-ing in Australia: ideas and lessons for a de-commodified sustainability tourism. Journal of Sustainable Tourism, 24(1): 91- 113.

Dwyer, L., Ateljević, I. i Tomljenović, R. (2017). Tourism Future: Towards Transformational Tourism. U: Dwyer, L., Tomljenović, R. i Čorak, S. (ur.), Evolution of destination planning and strategy: The rise of tourism in Croatia (str. 279-294). New York - London: Springer.

Kosnik, E. (2013). "Nourishing ourselves and helping the planet" WWOOF, Environmentalism and Ecotopia: Alternative Social Practices between Ideal and Reality. Doktorska disertacija. Wellington: Victoria University of Wellington.

Lean, G. L. (2009). Transformative travel: Inspiring sustainability. U: Bushel, R. i Sheldon, P. (ur.), Wellness and tourism: Mind, body, spirit, place (str. 191-205). New York: Cognizant.

McIntosh, A. i Bonnemann, S.(2006). Willing Workers on Organic Farms (WWOOF): The Alternative Farm Stay Experience? Journal of Sustainable Tourism, 14(1): 82-99.

Mcintosh, A. i Campbell, T. (2001). Willing Workers on Organic Farms (WWOOF): A neglected aspect of farm tourism in New Zealand. Journal of Sustainable Tourism, 9(2): 111-127. 
Miller, M. C. i Mair, H. (2015). Organic farm volunteering as a decommodified tourist experience. Tourist Studies, 15(2): 191-204.

Mostafanezhad, M. (2015). Organic farm volunteer tourism as social movement participation: a Polanyian political economy analysis of World Wide Opportunities on Organic Farms (WWOOF) in Hawai'i. Journal of Sustainable Tourism, 24(1): 114-131.

Nimmo, K. (2001). Willing Workers On Organic Farms: A Case Study. Wellington:Victoria University of Wellington.

Pollock, A. (2015). Social Entrepreneurship in Tourism - the Conscious Travel Approach. Oxford: Tourism Innovation Partnership for Social Entrepreneurship (TIPSE).

Pritchard, A., Morgan, N. i Ateljević, I. (2011). Hopeful Tourism: A New Transformative Perspective. Annals of Tourism Research, 38(3): 941-963.

Reisinger, Y. (ur.) (2013a). Transformational Tourism: Tourist Perspective. Wallingford: Centre for Agriculture and Bioscience International (CABI).

Reisinger, Y. (2013b). Connection between travel, tourism and transformation. U: Reisinger, Y. (ur.), Transformational Tourism: Tourist Perspective (str. 27-33). Wallingford: Centre for Agriculture and Bioscience International (CABI).

Reisinger, Y. (ur). (2015). Transformational Tourism: Host Perspective. Wallingford: Centre for Agriculture and Bioscience International (CABI).

Ross, S. (2010). Transformative travel: an enjoyable way to foster radical change. ReVision, 32(1): 54-61.

Terry, W. (2014). Solving labor problems and building capacity in sustainable agriculture through volunteer tourism. Annals of Tourism Research, 49: 94-107.

Tomljenović, R., Dukić, L. i Finci, D. (2015). Pilot istraživanje transformativnih turističkih poduzetnika: WWOOF domaćini u Hrvatskoj. Working paper No. 6. Zagreb: Institut za turizam.

WWOOF (2017). URL: http://www.wwoof.net/ (02.02.2017.)

WWOOF Croatia (2017). WWOOF Independents. URL: http://www.wwoofindependents.org/host-list/croatia/ (02.02.2017.)

WWOOF Independents (2017). URL: http://www.wwoofindependents.org (02.02. 2017.)

Yamamoto, D. i Engelsted, A. K. (2014). World Wide Opportunities on Organic Farms (WWOOF) in the United States : locations and motivations of volunteer tourism host farms. Journal of Sustainable Tourism, 22(6): 964-982. 


\title{
WWOOFING: A NEW MODEL OF TRANSFORMATIVE TOURISM IN CROATIA
}

\author{
Larisa Dukić, Irena Ateljević and Renata Tomljenović
}

\begin{abstract}
Summary
Travel as a catalyst for responsible citizens who want to change themselves and the world in which they live is a new social phenomenon. This paper will present an example of one such new trend called WWOOFing (World Wide Opportunities on Organic Farms), as a specific type of volunteerism in ecotourism, which can potentially become a model for transformative tourism in Croatia. In the methodological part of the paper, we analyse relevant literature and data available through the websites of independent organizations that practice WWOOFing. We also present the results of deep interviews conducted with the hosts of WWOOF in Croatia. The research reveals that the primary motivation of the hosts to implement WWOOF is: the additional assistance it provides, meeting new people and different cultures from around the world, and increasing the knowledge about sustainable ways of life and organic agriculture. The primary motivation of the volunteers to participate in WWOOFing is: the desire to learn and be actively involved in organic production and alternative ways of life, the desire to escape the everyday and search for new and authentic experiences, and the possibility for a cheaper way to travel. WWOOFing is considerably different from conventional tourism and has a large transformative potential based on: the workforce and cultural exchange, the opportunity for a direct involvement in the everyday lives of the hosts, as well as learning about organic agriculture and sustainability of alternative ways of life.
\end{abstract}

Key words: WWOOF, ecotourism, volunteer tourism, sustainability, transformation

\section{WWOOFING ALS NEUE FORM DES TRANSFORMATIVEN TOURISMUS IN KROATIEN}

\author{
Larisa Dukić, Irena Ateljević und Renata Tomljenović
}

\section{Zusammenfassung}

Heutzutage ist weltweit ein soziales Phänomen sichtbar, nämlich Reisen dienen als Katalisator dazu, dass verantwortungsvolle Menschen versuchen, sich und die Welt, in der sie leben, zu verändern. In dieser Arbeit stellen wir den Trend WWOOFing als eine spezifische Form des Freiwilligenökotourismus als ein potentielles Beispiel einer Art des transformativen Tourismus in Kroatien vor. Der angewandte methodologische Ansatz bestand aus der Analyse der Literatur und der Daten, die auf Webseite von unabhängigen Organisationen des WWOOF erreichbar sind, sowie aus Tiefinterviews mit WWOOF-Gastgebern in Kroatien. Die Forschung hat gezeigt, dass die primäre Motivation des Gastgebers für WWOOF aus der Sicherung einer zusätzlichen Hilfe auf dem Bauernhof, aus dem Kennenlernen von Menschen und Kulturen aus verschiedenen Teilen der Welt, sowie der Verbreitung der Idee der nachhaltigen Lebensweise und der organischen Landwirtschaft besteht. Die primäre Motivation der Volontäre für eine WWOOFing-Teilnahme besteht aus dem Wunsch nach Lernen und nach einer aktiven Teilnahme an der organischen Produktion und einer alternativen Lebensweise, Flucht vor dem Alltag und Suche nach neuen und authentischeren Erfahrungen, Möglichkeit einer billigeren Reise und eines billigeren Aufenthaltes am Reiseziel. WWOOFing unterscheidet sich im bedeutenden Maße vom konventionellen Tourismus und zeigt ein ausgeprägtes transformatives Potential, das auf der Erfahrung von Arbeits- und Kulturaustausch beruht, einem direkten Einschluß in den Alltag des Gastgebers und aus dem Lernen über die organische Landwirtschaft und die Nachhaltigkeit der alternativen Lebensweise besteht.

Schlüsselwörter: WWOOF, Ökotourismus, Freiwilligentourismus, Nachhaltigkeit, Transformation 